\title{
The Problems and Countermeasures of Financial Management in Colleges and Universities
}

\author{
Biao Liu \\ Jiangxi Science \& Technology Normal University, finance department, \\ Jiangxi, Nanchang, 330013
}

\begin{abstract}
At present, the construction scale of the ordinary colleges and universities in our country is gradually increasing. In order to the develop colleges and universities, the internal management of colleges and universities is becoming more and more important, and the financial management of colleges and universities is a very important link. School financial management directly affects the daily teaching work and school scientific research work, so it is necessary to strengthen the financial management of ordinary colleges and universities. However, there are a series of problems in the daily financial management of colleges and universities. This paper analyzes a series of problems in the daily financial management of ordinary colleges and universities and put forward corresponding solutions on this basis.

Keywords: ordinary colleges and universities; financial management; daily teaching; problems; solutions
\end{abstract}

\section{Introduction}

With the arrival of the 21 st century, Chinese social economy has been rapid development, the market gradually diversified. In recent years, Chinese ordinary institutions of higher learning have been actively reforming and developing. Under the stimulation of the social market economy, the running of colleges and universities in our country has gradually become a market-oriented school, which has a great impact on the related economic activities. In the past, the activities of 
ordinary institutions of higher learning are funded by the national financial unity, nowadays, the activities of ordinary institutions of higher learning funded by the state finance most of the funding, a small part of the activities funded by market channels to raise. As Chinese social market economic rules and regulations gradually improved, colleges and universities should strengthen internal financial management, so that colleges and universities in accordance with the current market rules, the school effectively play the only funds to the school to bring more education funding, making ordinary The daily teaching work and scientific research work of colleges and universities are effectively guaranteed, so as to effectively promote the development of education in ordinary institutions of higher learning. This paper will address the problems in the financial management of colleges and universities, put forward the feasibility of countermeasures, will be of great significance to school financial management.

\section{2 . Problems in the financial management of ordinary colleges and universities}

Chinese ordinary institutions of higher learning in recent years is also actively reform and development, the social market economy, stimulated, Chinese ordinary institutions of higher learning school gradually evolved into the market, the school's economic activities have had a tremendous impact, it is necessary to strengthen the school The financial management, but in the process of financial management, there have been a series of problems. The details are as follows:

\subsection{Inadequate budgetary management and discretionary appropriation of funds}

Colleges and universities in the conduct of financial management, it should be on the school budget for education, the main content is for the ordinary colleges and universities of income and expenditure. But in the actual process, the ordinary colleges and universities plan to increase teaching and research activities, resulting in school spending budget is completely no feasibility. The educational budget of ordinary colleges and universities is very limited, and the financial budget management is carried out. The teaching and research work and the scientific research work of ordinary institutions of higher learning are clearly defined, and the financial resources of the schools are fully considered. But some of the school sector to increase the designated research projects, did not give full consideration to the financial resources of the school, leading to some designated teaching and research projects can not be carried out, and even school leaders with the misappropriation of school funds, making the school financial budget management confusion. 


\subsection{There are a variety of channels of school capital market sources and there is a series of risks}

At present, Chinese general higher education funding sources are relatively broad, including the state financial allocations, education, tuition and fees, scientific research patent income, school-run industries and bank financial loans. In which state financial allocations are the main sources of funding for higher education in general colleges and universities, and other sources can only sustain the school's ordinary day-to-day operating expenses. However, there is a certain competition in the market economy. If there is a problem in the management of the school industry, it will inevitably lead to a loss, which will lead to the daily expenditure of the school. Therefore, the bank has a great impact on the normal education activities. Bank financial loans are the main channels for the general colleges and universities to solve the lack of funding activities, but we understand that the bank loan is a certain interest. Therefore, ordinary colleges and universities in the event of serious debt over the repayment ability of the school, it will inevitably lead to general higher education financial paralysis.

\subsection{There are complete reimbursement procedures and project protection issues}

At present, in accordance with the existing financial management rules and regulations, all reimbursement work to the financial sector for specialized processing, in the process, the need for financial reimbursement personnel carefully reimbursement projects, reimbursement of the amount of project managers, project approvers as well as the signature of the project leaders to fill out in detail, as long as the guarantee procedures are complete, the financial sector to carry out project reimbursement. But in the actual process, the project reimbursement often also incomplete procedures can also be reimbursed [3]. In the project reimbursement, the reimbursement of the content often appear false, and the actual does not meet the same time, the project manager in the reimbursement of the project, the project approver and the project leader's signature is not a physical screening, just by project invoice So as to effectively help some profit-making elements, better to do a false insurance policy, which led to regular higher education institutions often occur misappropriation of funds.

\section{3 . The solve problems countermeasures of university financial management}

In the current social market economy, the emergence of a series of factors above is diverse, such as ordinary institutions of higher learning

Of the financial management personnel are not fully aware of the importance of school financial management and financial management personnel have not yet learned that the school has to market-oriented school. In order to ensure the financial management of colleges and universities effectively, it is necessary to 
strengthen the financial management of ordinary colleges and universities, give full play to the role of financial management, and promote the development of education in ordinary institutions of higher learning. The details are as follows:

\subsection{The correct treatment of the budget, strengthen financial control}

In order to ensure the rational arrangement of the teaching work and scientific research activities of colleges and universities to be effectively protected, it is necessary to carry out the financial budget of ordinary institutions of higher learning. Before the financial budget, the need for ordinary colleges and universities throughout the year may have to teaching and research activities and scientific research activities for analysis, through scientific research, develop annual activities and the preparation of [4]. In this process, to do the following three steps. First, in the actual teaching and research activities, it is necessary to strictly implement budget management to develop programs to strengthen the management of funds; second, once the ordinary colleges and universities operating, teaching and research activities and scientific research activities under normal circumstances do not change, it is necessary to increase teaching and research half- Third, improve the relevant budgetary funds management and supervision and management rules and regulations, in the relevant project activities, the excess funds to conduct a rigorous review, an effective solution to the budget, the budget will be adjusted, Expenditure and actual expenditure.

\subsection{Establish risk awareness}

In order to realize the sustainable development of ordinary colleges and universities, it is necessary to collect the tuition and fees of the students at the beginning of school, to set reasonable fees and reduce the shortage of education funds. In the school-run industry, the departments increase information coordination, and strive to do a good job in the market. In the aspect of bank loans, it is necessary to set up a scientific loan amount to ensure the sufficient funds for school education activities and to ensure the school-related repayment ability.

\subsection{Improve the financial management rules and regulations}

The financial management of colleges and universities to effectively guarantee measures is to improve the relevant financial management rules and regulations. In the course of improving the relevant rules and regulations of financial management of ordinary institutions of higher learning, we should combine the dynamic development of the school. In order to ensure the feasibility of the school financial management rules and regulations, and effectively play the role of financial management rules and regulations, regular institutions of higher learning should be regular rules and regulations should be modified. Strict expenditure of school sales to the financial sector for specialized processing, in the process, the need for financial reimbursement staff carefully reimbursement of the project, the amount of reimbursement, project managers, project approvers 
and project leaders of the relevant signatures to fill in detail, As long as the guarantee procedures are complete, the financial sector to carry out project reimbursement.

\section{Conclusion}

In summary, with the development of Chinese higher education institutions, internal management is becoming more and more important and financial management is one of the particularly important parts. For the effective use of education funding to ensure the normal operation of colleges and universities, we need to strengthen the school financial management, but there are a series of problems in the process of financial management, such as the lack of budgetary funds management and the misappropriation of funds and the various sources of school capital market sources, there is a series of risks, etc. Therefore, we need to correctly treat the budget, strengthen the control of funds and establish risk awareness. I believe that Chinese general higher education financial management will be further enhanced and lay a solid foundation for the development of higher education.

\section{References}

[1] Liu Bo. Optimization of Financial Management in Colleges and Universities in Ethnic Areas - Taking the promulgation and implementation of new "financial system of colleges and universities" as an opportune moment. National Education Research, 55(12), pp.68-70, 2011

[2] Ding Fei-hong. The Problems and Solutions in the Management of Financial Budget in Colleges and Universities. Medium and Small Enterprise Management and Technology (in Chinese), 8 (5), pp.87- 91, 2013

[3] Li Wenjing. Analysis of high school financial management personnel on the employment system of the existing problems and solutions. Financial sector (academic), 12(10), pp. 18- 20, 2012

[4] Yan Dabo, Yang Tongtong, Zhang Cheng and other schools of financial management information construction thinking. Journal of Shenyang Agricultural University (Social Science Edition), 9(6), pp.58- 61, 2011.

[5] Luo Weifeng, Wu Le. The research on the problems of financial information disclosure in colleges and universities - Based on the perspective of "financial system of colleges and universities", Friends of Accounting, 8(4), pp.85-87, 2014 